\title{
MAP SHOWING DISTRIBUTION OF ALKALINE IGNEOUS ROCKS AND ASSOCIATED CARBONATITES AND PERIDOTITES IN THE NORTHERN MIDCONTINENT, U.S.A.
}

\author{
Compiled by \\ F. Allan Hills', Richard W. Scott, Jr.1,
Theodore J. Armbrustmacher1, and Pieter Berendsen ${ }^{2}$
}

\section{INTRODUCTION}

This 1:1,000,000-scale map of the northern Midcontinent area shows the locations of alkaline igneous rocks and associated carbonatites and mica peridotites, and of structural domes and diatremes known or thought to be associated with similar igneous rocks. In addition, it shows the location of other structural features and geophysical anomalies of uncertain origin that may be related to buried igneous rocks. These include cryptoexplosion features, some of which have been interpreted as astroblemes, and gravity and magnetic anomalies that have been interpreted to result from buried mafic plutons. Precambrian igneous rocks having a wide range of compositions are exposed or buried at shallow depth in South Dakota, Minnesota, and Wisconsin, and they are found beneath the Paleozoic strata throughout the study area. Only those Precambrian rocks that are clearly alkaline, carbonatitic, or kimberlitic are included in this compilation. Table 1 shows a summary of available information on the petrology, structural setting, and age of each occurrence or group of occurrences and lists the principal references for each. Because the authors have not studied most of the occurrences in this compilation, they made no attempt to change the rock terminology to make it consistent or up to date. Generally, the name used for each occurrence is the one in the most recent, cited publication on the occurrence. Figures 1 and 2 are larger scale maps that show the locations of igneous rocks and diatremes where they are clustered too closely to be shown clearly on the main map.

This map is part of a folio of maps and cross sections of the northern Midcontinent area (bounded by lats $36^{\circ}-46^{\circ} \mathrm{N}$. and longs $88^{\circ}-100^{\circ} \mathrm{W}$.) prepared under the Midcontinent Strategic and Critical Minerals Project. This project is a cooperative activity between the U.S. Geological Survey and the

\footnotetext{
1U.S. Geological Survey, Denver, CO 80225.

${ }^{2}$ Kansas Geological Survey, Lawrence, KS
}

geological surveys of the included States. Other maps in this follo to date include U.S. Geological Survey Miscellaneous Field Studies Maps MF-1835-A through E (Mugel, 1986; Jorgensen and others, 1986; Marvin, 1988; Pratt, 1987; Anderson, 1988) and U.S. Geological Survey Miscellaneous Investigations Service Map I-1853-A (Sim. 1990).

\section{REFERENCES CITED}

Amos, D.H., 1967, Geologic map of part of the Smithland quadrangle, Livingston County, Kentucky: U.S. Geological Survey Geologic Quadrangle Maps of the United States, Map GQ-657, scale 1:24,000.

Anderson, R.R., compiler, 1988, Phaneroroic structural features in the northern Midcontinent, U.S.A.: U.S. Geolcrical Survey Miscellaneous Field Studies Map MF-1835-E, scale 1:1,000,000.

Baxter, J.W., Desborough, G.A., and ShèrN, C.W., 1967, Areal geology of the Illinois fluorspar district, Pt. 3--Herod and Shetlervil'? quadrangles: Illinois State Geologi al Survey Circular 413, $41 \mathrm{p}$.

Berendsen, P., Cullers, R.L., Mansker, W.L., and Cole, G.P., 1985, Late Cretaceous kimberlite and lamproite occurrences in eastern Kansas, U.S.A.: Geological Society of Amprica Abstracts with Programs, v. 17, no. 3; p. 151.

Bickerman, M., Lidiak, E.G., and Lewis, Richard, 1982, K-Ar ages of phlogopite from mica peridotite, Omaha oil field intrusion. Gallatin County, southern Illinois: Geological Society of America Abstracts with Prograrrs. v. 14, no. 5, p. 255.

Bickford, M.E., Mose, D.H., Wetherill, G.IN., and Franks, P.C., 1971, Metamorphism of Precambrian granitic xenoliths in a mica peridotite at Rose dome, Woodson County, Kansas--Part 1, Rb-Sr isotope stud 's: Geological Society of America Bulletin, v. 82, p. 2863-2868. 
Brock, M.R., and Heyl, A.V., Jr., 1961, PostCambrian igneous rocks of the central craton, western Appalachian Mountains, and Gulf Coastal Plain of the United States, in Short papers in the geologic and hydrologic sciences: U.S. Geological Survey Professional Paper 424-D, p. D33-D35.

Brookins, D.G., 1970a, Kimberlite at Winkler crater, Kansas: Geological Society of America Bulletin, v. 81, p. 241-246.

$1970 \mathrm{~b}$, The kimberlites of Riley County, Kansas: Kansas State Geological Survey, Bulletin 200, 32 p.

Brookins, D.G., Della Valle, R.S., and Bolivar, S.L., 1976, Uranium geochemistry of some United States kimberlites [abs.]: American Geophysical Union Transactions (EOS), v. 57, p. 762.

Brown, J.S., Emery, J.A., and Meyers, P.A., Jr., 1954, Explosion pipe in test well on Hicks Dome, Hardin County, Illinois: Economic Geology, v. 49, p. 891-902.

Clegg, K.E., 1955, Metamorphism of coal by peridotite dikes in southem Illinois: Illinois Geological Survey Report of Investigations, no. 178, p. 5-18.

Clegg, K.E., and Bradbury, J.C., 1956, Igneous intrusive rocks in Illinois and their economic significance: Illinois Geological Survey Report of Investigations, no. 197, 19 p.

Cordua, W.S., 1985, Rock Elm structure, Pierce County, Wisconsin-A possible cryptoexplosion structure: Geology, v. 13, p. 372-374.

Cullers, R.L., Mullenax, J., Di Marco, M.J., and Nordeng, S., 1982, The trace element content and petrogenesis of kimberlites in Riley County, Kansas, U.S.A.: American Mineralogist, v. 67, p. 223-233.

Cullers, R.L., Ramakrishnan, S., Berendsen, P., and Griffin, T., 1985, Geochemistry and petrogenesis of lamproites, Late Cretaceous age, Woodson County, Kansas, U.S.A.: Geochimica et Cosmochimica Acta, v. 49, no. 6, p. 1383-1402.

Englehardt, R.L., 1973, The petrology of some igneous dikes of western Kentucky: Richmond, Ky., University of Eastem Kentucky M.S. thesis, 59 p.

English, R.M., and Grogan, R.M., 1948, Omaha pool and mica-peridotite intrusives, Gallatin County, Illinois: Illinois Geological Survey Report of Investigations, no. 130 , p. 189-212.

Franks, P.C., 1959, Pectolite in mica peridotite, Woodson County, Kansas: American Mineralogist, v. 44, p. $1082-1086$.

Greenberg, J.K., and Brown, B.A., 1985, Deformational and metamorphic features associated with 1,500-Ma anorogenic magmatism in Wisconsin, in Tithis, August, ed., The crust--The significance of granites/gneisses in the lithosphere: Theophrastus Publications, p. 79-92.

Grohskopf, J.G., 1955, Subsurface geology of the Mississippi embayment of southeast Missouri: Missouri Division of Geological Survey and Water Resources [Report], 2nd ser., v. 37, $133 \mathrm{p}$.

Harlem, C.L., 1982, The Elk Creek Carbonatites, in Schultz, C. B., ed.: Nebraska Academy of Sciences and Affiliated Societies Proceedings, v. 92 , p. $48-49$.

Hendriks, H.E., 1965, The Crooked Creek structure in Snyder, F.G., and others, Cryptoexplosion structures in Missouri--Geological Society of Amercia Guidebook, 1965 Annual Meeting: State of Missouri Report of Investigations no. 30, p. 68-72.

Heyl, A.V., Jr., and Mckeown, F.A., 1978, Preliminary seismotectonic map of the central Mississippi Valley and environs: U.S. Geological Survey Miscellaneous Field Studies Map MF-1011, scale 1:500,000.

Hildenbrand, T.G., Kane, M.F., and Stauder, S.J., 1977, Magnetic and gravity anomalies in the northern Mississippi embayment and their special relation to seismicity: U.S. Geological Survey Miscellaneous Field Studies Map MF914, scale 1:1,000,000.

Jorgensen, D.G., Helgesen, J.O., Leonard, R.B., and Signor, D.C., 1986, Equivalent freshwater head and dissolved-solids concentration of water in rocks of Cambrian, Ordovician, and Mississippian age in the northern Midcontinent, U.S.A.: U.S. Geological Survey Miscellaneous Field Studies Map MF-1835-B, scale 1:1,000,000.

Kidwell, A.L., 1947, Post-Devonian igneous activity in southeastem Missouri: State of Missouri Department of Business and Administration, Division of Geological Survey and Water Resources, Report of Investigations no. 4, 83 p.

Kisvarsanyi, E.B., and Howe, W.B., 1983a, The southeast Missouri minerals district and its relationship to post-Precambrian igneous activity: Missouri Geological Survey map no. OFM-83-170a-GI, scale 1:250,000. 1983b, Bee Fork center contoured on the top of the volcaniclastic facies: Missouri Geological Survey map no. OFM-83-170b-GI, scale 1:24,000.

1983c, Cross section A-A', Bee Fork: Missouri Geological Survey map no. OFM-83$170 \mathrm{c}-\mathrm{GI}$

1983d, Isopach map of volcaniclastic facies in the lower Bonneterre Formation along the Viburnum trend (Bee Fork area): Missouri Geological Survey map no. OFM-83-170d-GI, scale $1: 24,000$.

$1983 e$, The Bee Fork volcanic center and its relationship to the southeast Missouri lead- 
zinc district: Geological Society of America Abstracts with Programs, v. 15, no. 6, p. 614 . Kisvarsanyi, E.B., Pratt, W.P., and Heyl, A.V., Jr., 1981, Fluorine-thorium and rare-earth-bearing kimberlitic carbonatite complexes, in Pratt, W.P., ed., Metallic mineral resource potential of the Rolla $1^{\circ} \times 2^{\circ}$ quadrangle, Missouri, as appraised in September, 1980: U.S.

Geological Survey Open-File Report 81-518, p. 35-40.

Knight, G.L., and Landes, K.K., 1932, Kansas laccoliths: Journal of Geology, v. 40, p. 1-15.

Koenig, J.B., 1956, The petrography of certain igneous dikes of Kentucky: Kentucky Geological Survey Series 9, Bulletin 21, 57 p.

LaBerge, G.L., and Meyers, P.E., 1983, Precambrian geology of Marathon County, Wisconsin: Wisconsin Geological and Natural History Survey, Information Circular 45, $88 \mathrm{p}$.

Lewis, Richard, 1982, Petrology and mineralogy of the monticellite alnoite associated with the Omaha oil field, Gallatin County, lllinois: Geological Society of America Abstracts with Programs, v. 14, no. 5, p. 265.

Lockwood, R.P., 1967, Petrologic study of syenites near Wausau, Wisconsin: University of Wisconsin at Madison M.S. thesis, 72 p. 1970 , Petrology of syenites, Wausau, Wisconsin: The Compass of Sigma Gamma Epsilon, v. 48, no. 1, p. 32-44.

Mansker, W.L., Richards, B.D., and Cole, G.P., 1985, A review and comparison of Kansas kimberlites: Geological Society of America Abstracts with Programs, v. 17, no. 3, p. 166.

Marvin, R.F., compiler, 1988, Radiometric ages of basement rocks in the northern Midcontinent, U.S.A.: U.S. Geological Survey Miscellaneous Field Studies Map MF-1835-C, scale 1:1,000,000.

McDowell, R.C., Grabowski, G.J., Jr., and Moore, S.L., 1981, Geologic map of Kentucky: U.S. Geological Survey in cooperation with 10th and 11th Kentucky Geological Surveys, scale $1: 250,000$.

Meyer, H.O.A., and Brookins, D.G., 1976, Sapphirine, sillimanite, and garnet in granulite xenoliths from Stockdate kimberlite, Kansas: American Mineralogist, v. 61, p. 1194-1202.

Mugel, D.N., compiler, 1986, Map showing availability of data for selected deep drill holes in the northern Midcontinent, U.S.A: U.S. Geological Survey Miscellaneous Field Studies Map MF-1835-A, scale 1:1,000,000.

Offield, T.W., and Pohn, H.A., 1979, Geology of the Decaturville impact structure, Missouri: U.S. Geological Survey Professional Paper 1042, $48 \mathrm{p}$.

Pratt, W.P., compiler, 1987, lospach and lithofacies map of the Sauk sequence (excluding basal clastics) in the northem Midcontinent, U.S.A.:
U.S. Geological Survey Miscellanesus Field

Studies Map MF-1835-D, scale 1: $\uparrow, 000,000$.

Sayeed, U.A., Smith, R., and Carlson, M.P., 1972, Geophysical anomaly around Stell", Richardson Co., Nebraska: Geolc rical Society of America Abstracts with Programs, v. 4 , no. 6, p. 407.

Sims, P.K., compiler, 1990, Precambrian basement map of the northern Midcontinent, U.S.A.: U.S. Geological Survey Miscellaneous Investigations Series Map I-1853-A, scale $1: 1,000,000$.

Snyder, F.G., and Gerdemann, P.E., 1965, Explosive igneous activity along an Illinois-MissouriKansas axis: American Joumal of Science, v. 263, p. 465-493.

Snyder, F.G., Williams, J.H., and others, 1965, Cryptoexplosive structures in MissouriGeological Society of America Gui tebook, 1965 Annual Meeting: State of Missouri Report of Investigations no. 30, 73 p.

Trace, R.D., 1966, Geologic map of the Marion quadrangle, Crittenden and Caldw 11 Counties, Kentucky: U.S. Geological Surve! Geologic Quadrangle Maps of the U.S., Mar GQ-547, scale 1:24,000.

Trace, R.D., and Amos, D.H., 1984, Stratigraphy and structure of the western Kentucky fluorite district: U.S. Geological Survey F nfessional Paper 1151-D, $41 \mathrm{p}$.

Treves, S.B., Burchett, R.R., and Low, L.J., 1982, Precambrian investigations in east ? $\mathrm{m}$ Nebraska: Geological Society of $f$ merica Abstracts with Programs, v. 14, r ?. 3, p. 138.

Wagner, H.C., 1954, Geology of the Fredonia quadrangle, Kansas: U.S. Geolog'ral Survey Geologic Quadrangle Map GQ-49, scale $1: 62,500$.

Wagner, R.E. and Kisvarsanyi, E.B., 196؟, Lapilli tuffs and associated pyroclastic sediments in Upper Cambrian strata along Dent Branch, Washington County, Missouri: Missouri Geological Survey and Water Resnurces Report of Investigations no. 43, 80 p.

Weller, J.M., Grogan, R.M., and Tippie, F.E., 1952, Geology of the fluorspar deposits of Illinois: Illinois State Geological Survey Bu"letin 76, $147 \mathrm{p}$.

Weller, Stuart, and Sutton, A.H., 1951, Geology of the western Kentucky fluorspar dirtrict: U.S. Geological Survey Mineral Investiçations Field Studies Map MF-2, scale 1:24,000.

Willman, H.B., and others, compilers, 1967, Geologic map of lllinois: Illinois State Geolc rical Survey, scale 1:500,000.

Zartman, R.E., Brock, M.R., Heyl, A.V., clr., and Thomas, H.H., 1967, K-Ar and RI Sr ages of some alkalic intrusive rocks from contral and eastern United States: American Journal of Science, v. 265 , p. 848-870. 


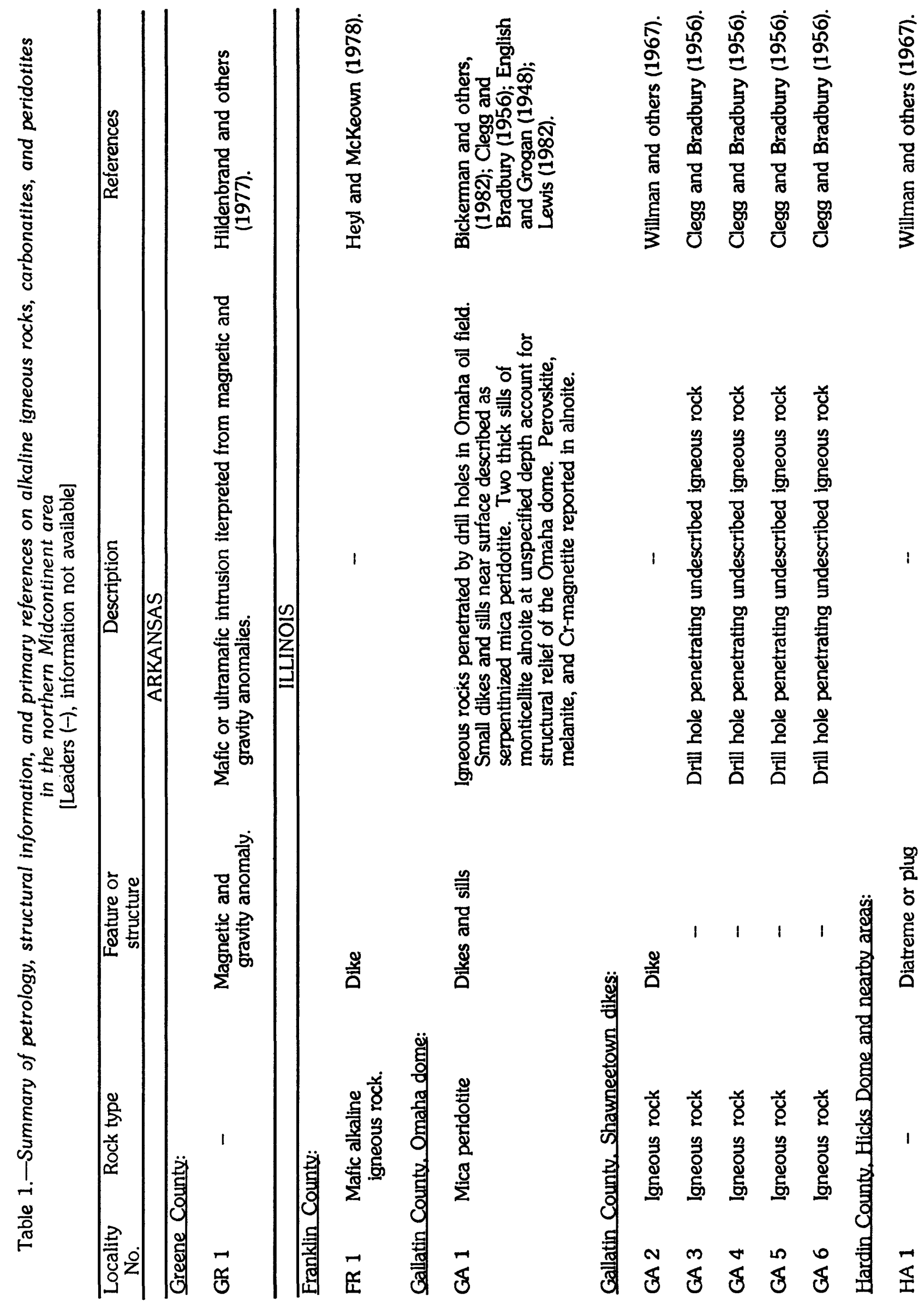



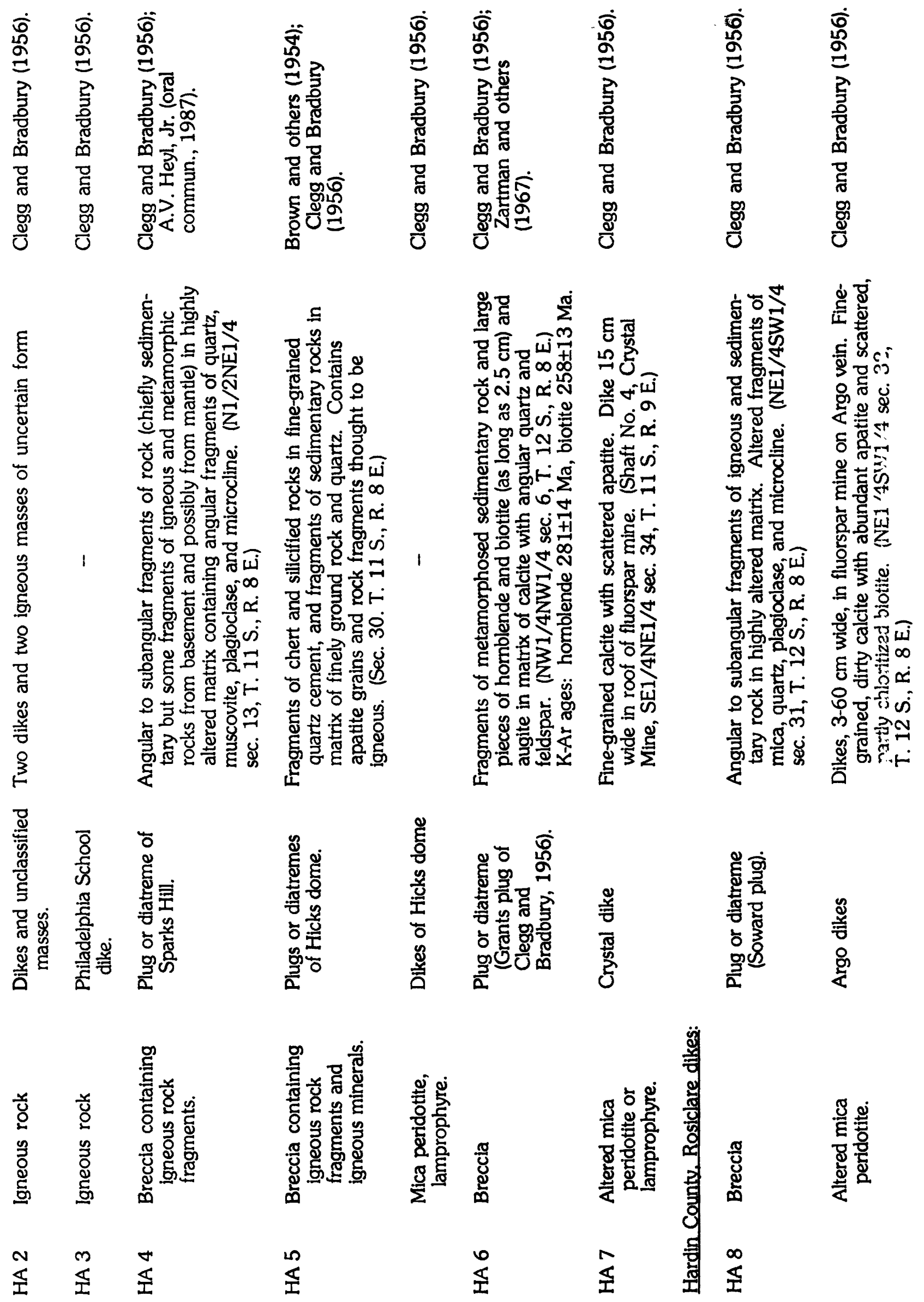

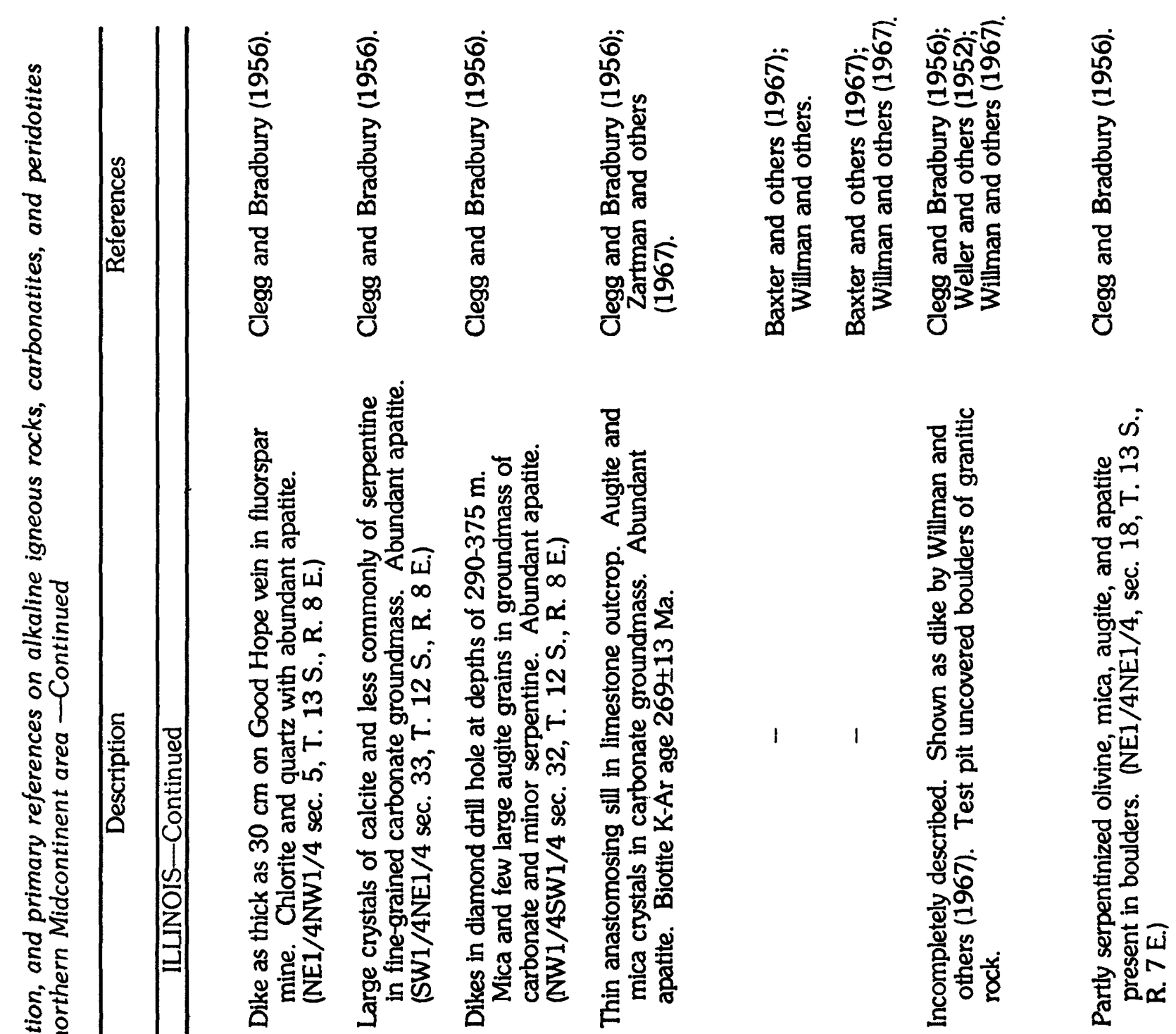

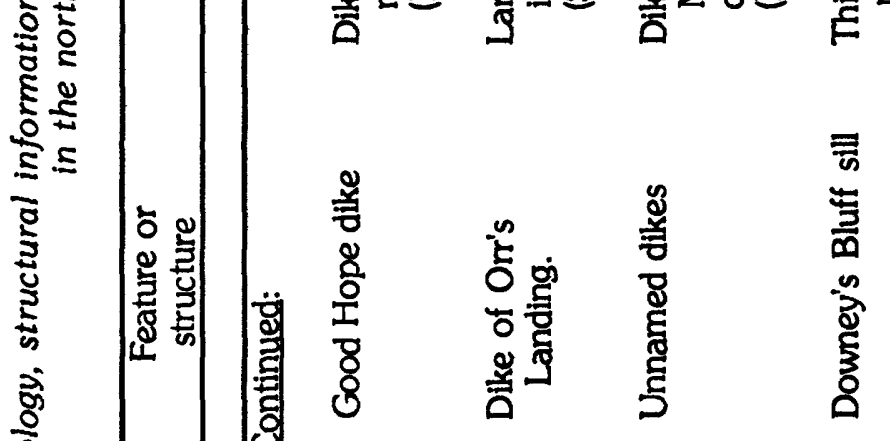




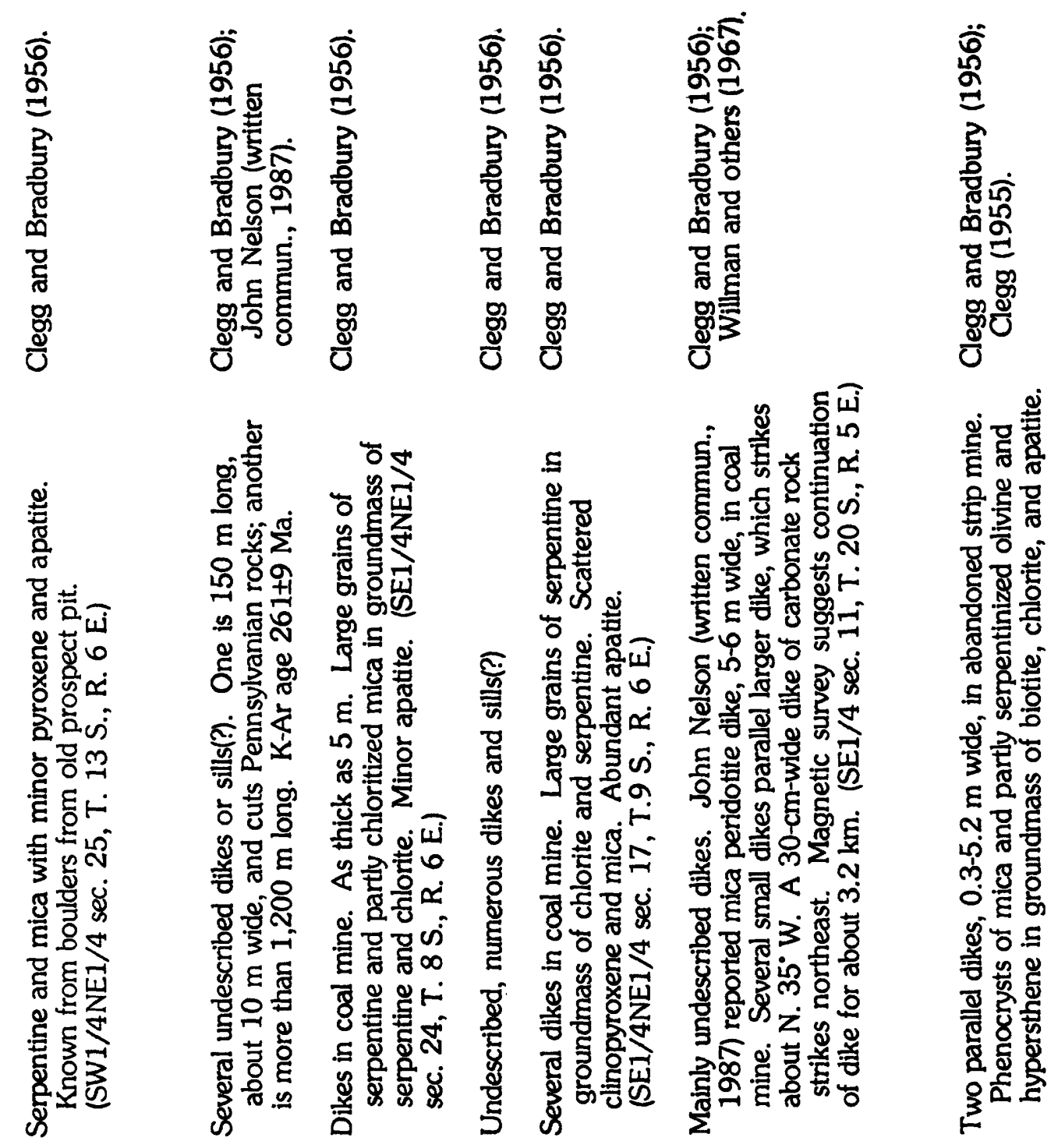

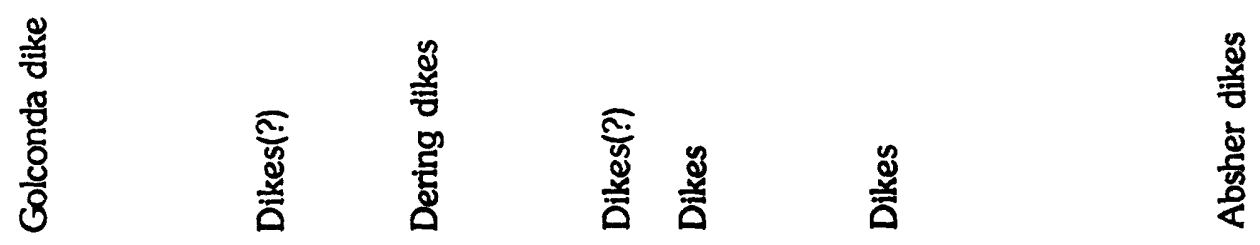

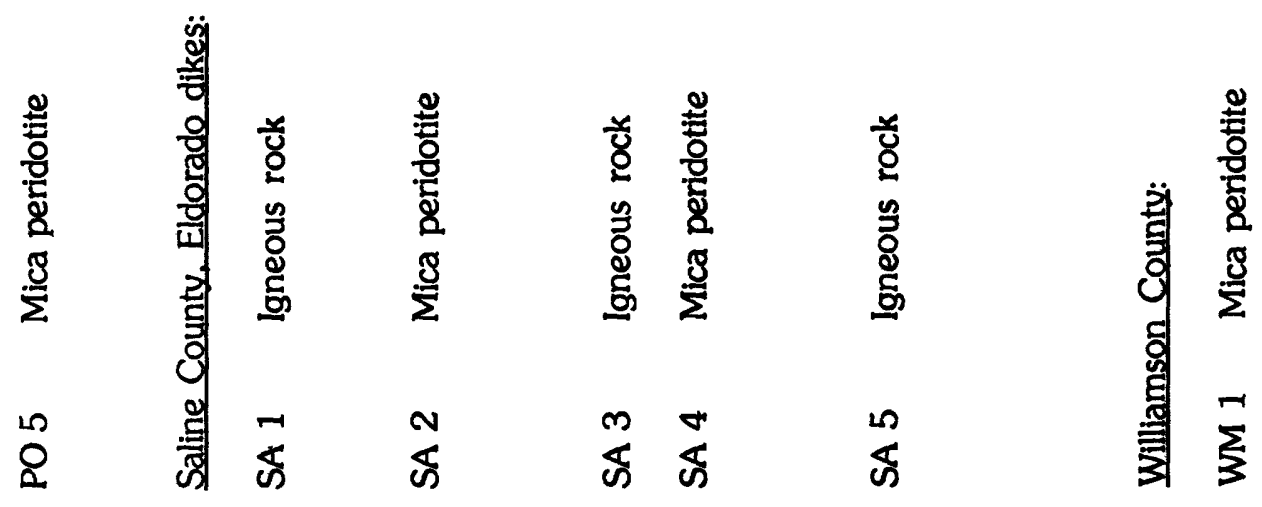




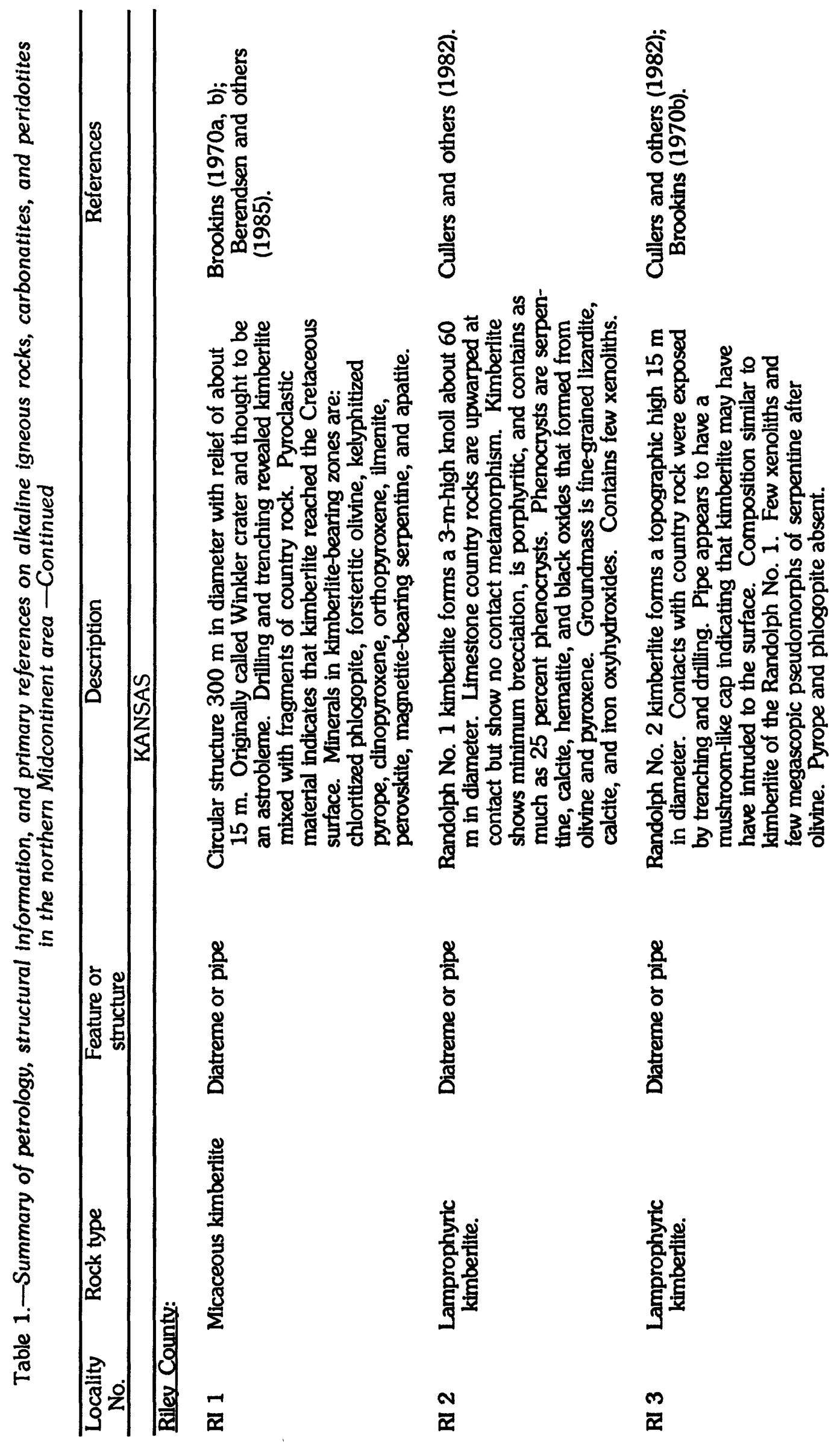




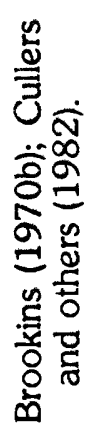

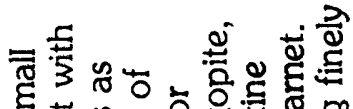
ผ

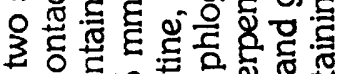

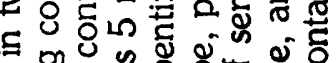
.

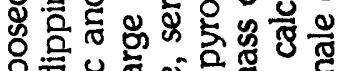

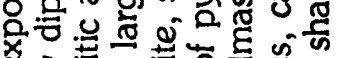

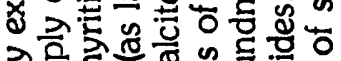

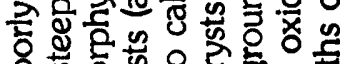

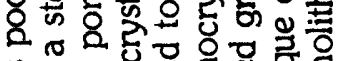

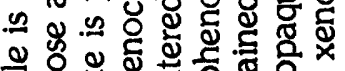

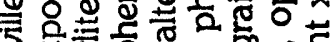

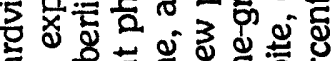

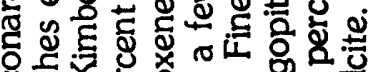

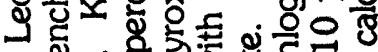

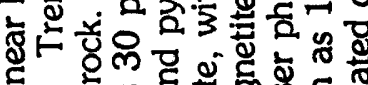

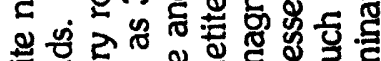

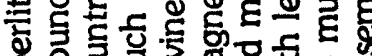

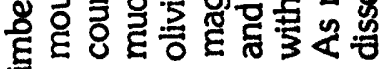

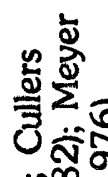

호월

월

ธै

8 등

ตั

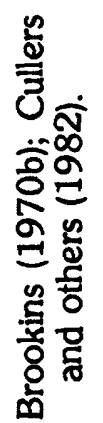

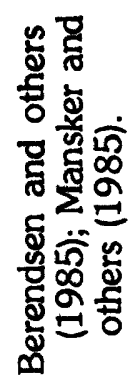

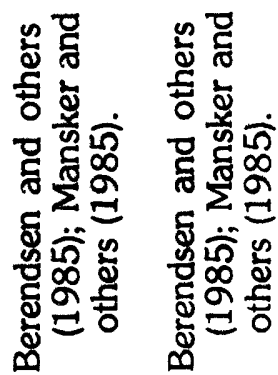

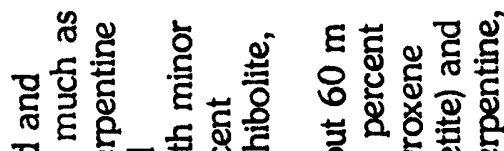

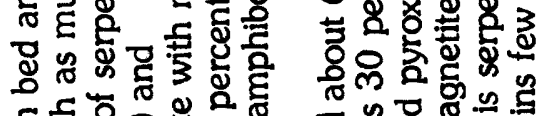

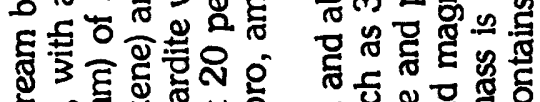

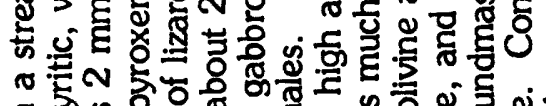

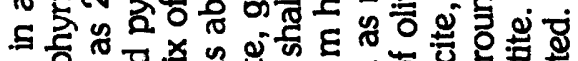

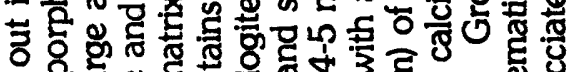

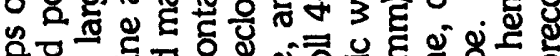

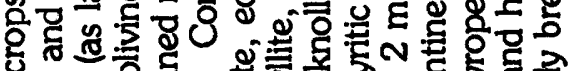

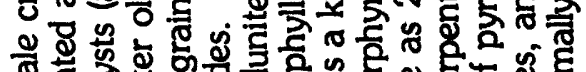

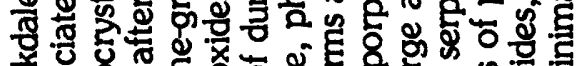

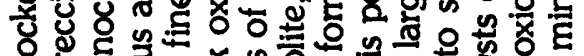

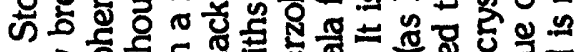

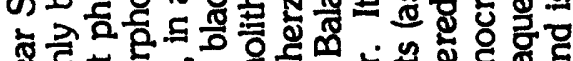

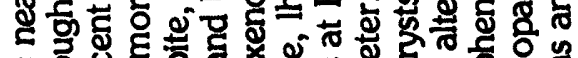

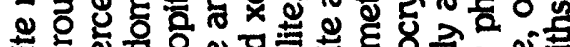

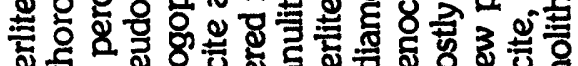

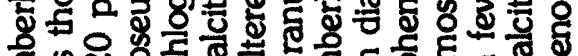

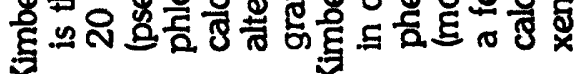
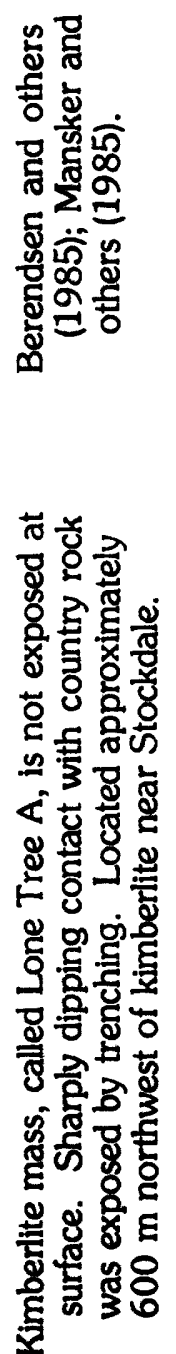

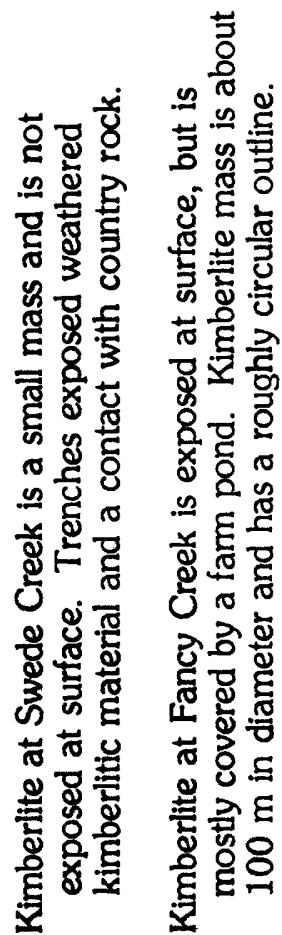

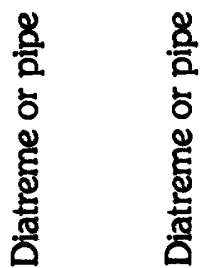

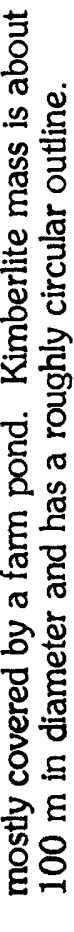

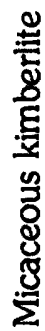

$\nabla$
总

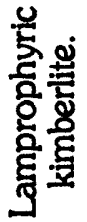

$\stackrel{20}{7}$

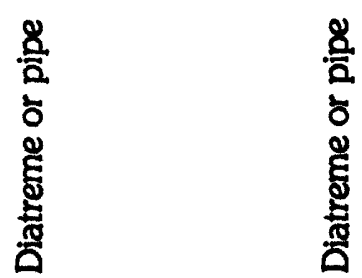

$\stackrel{0}{x}$

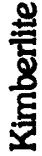

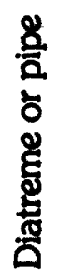

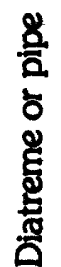

萦

존 


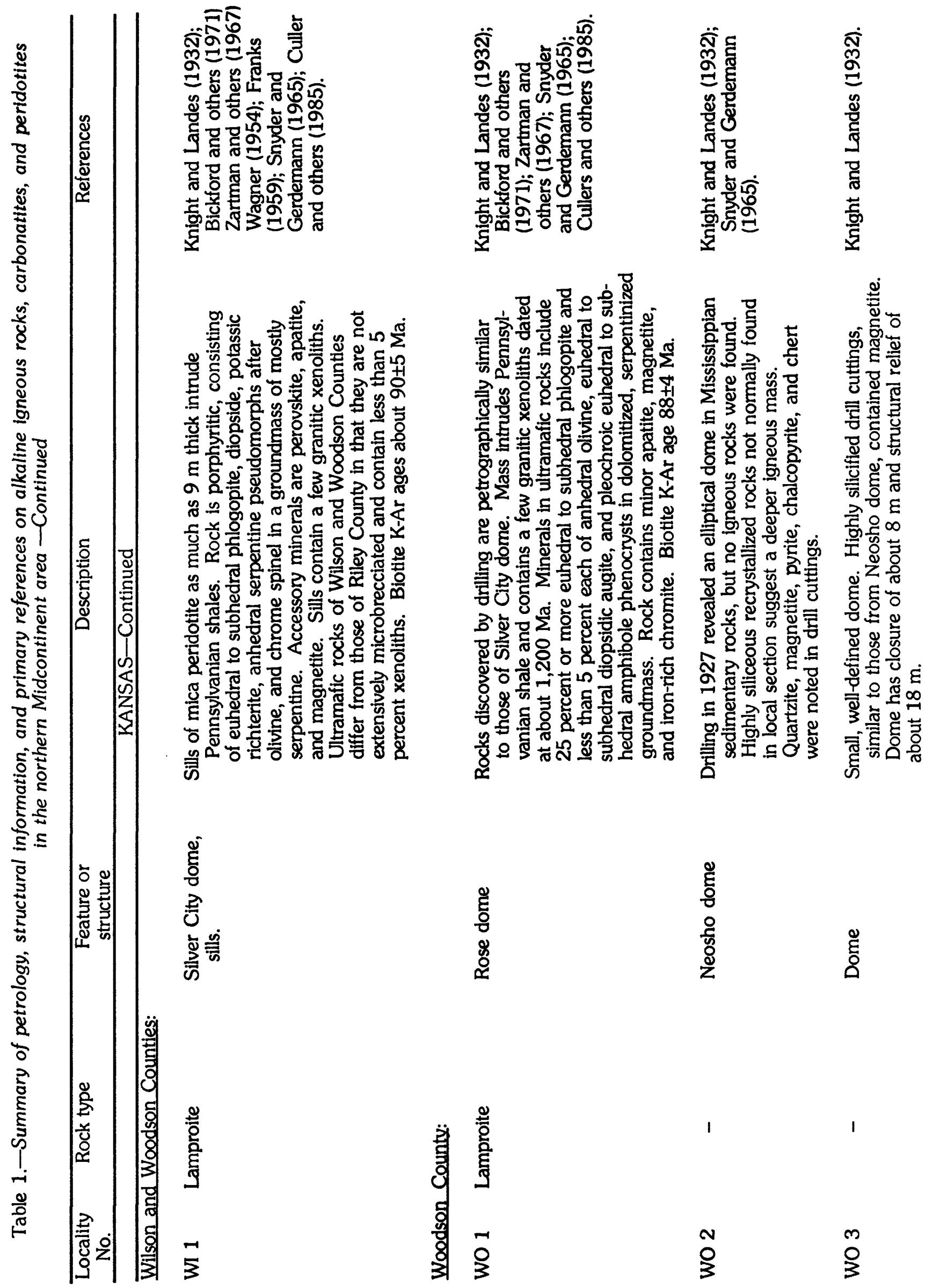




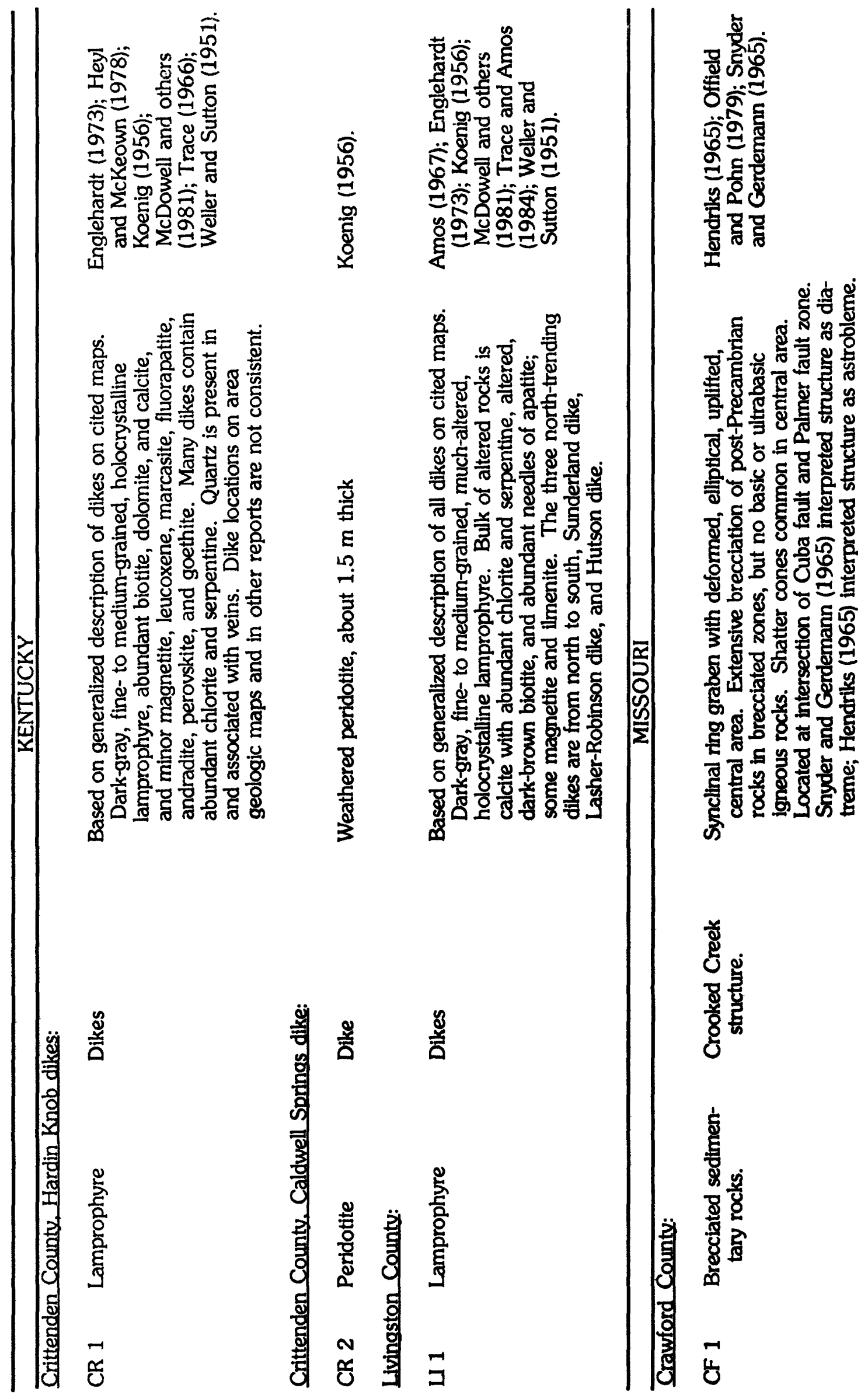




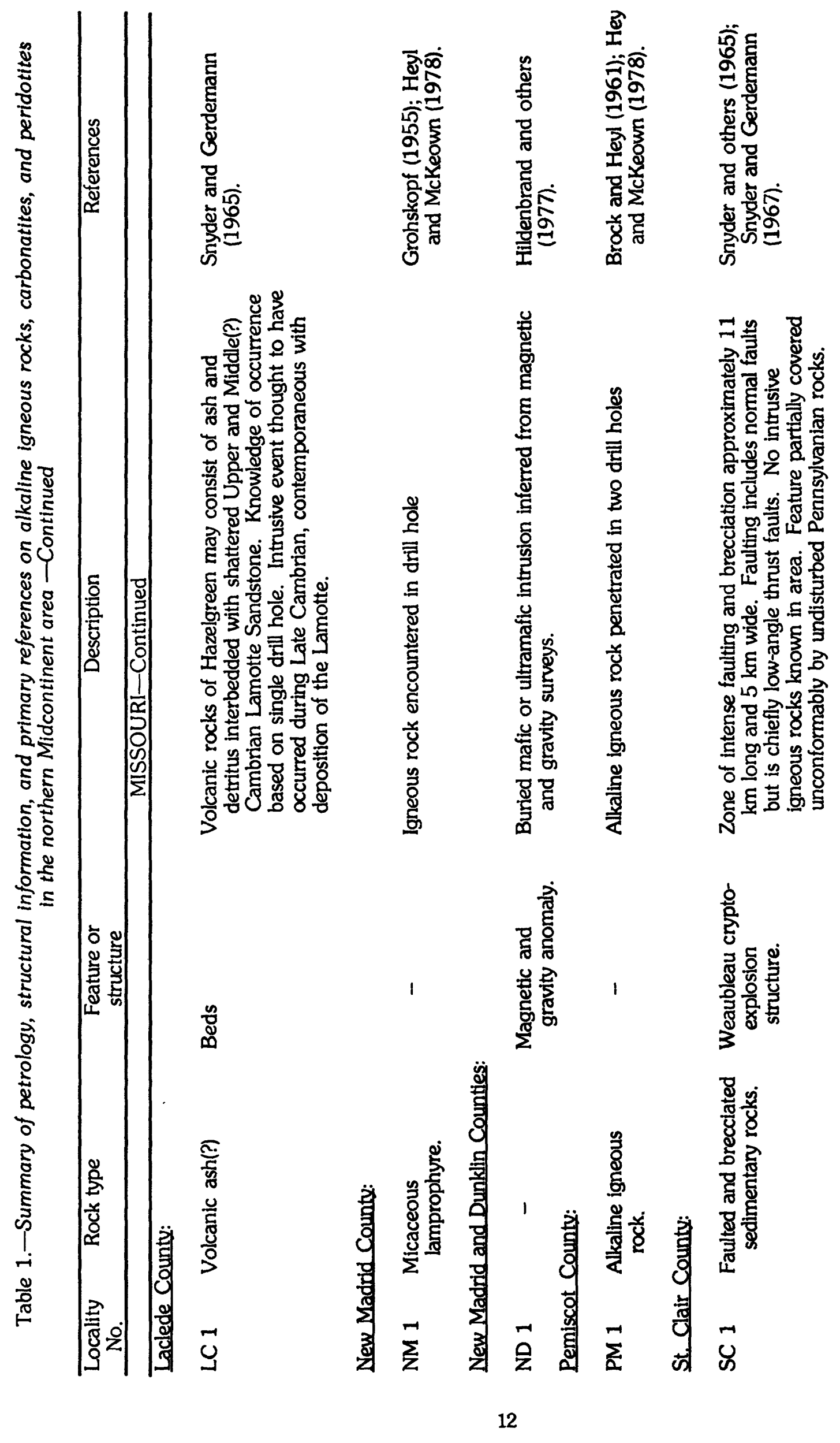




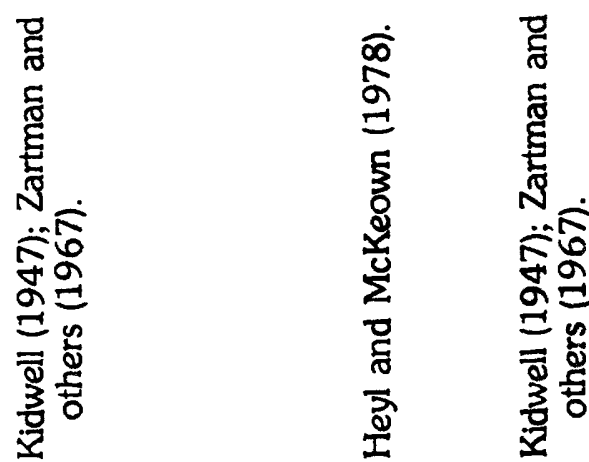

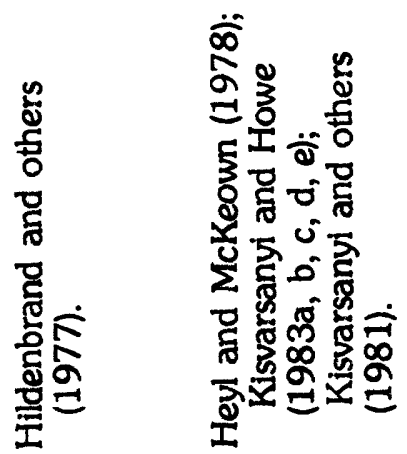

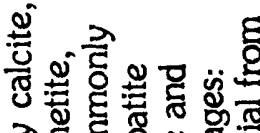

र造

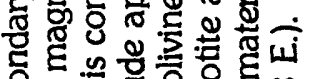

0.

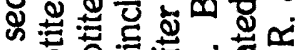

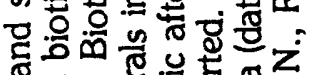

ว.

क्र

ह 80

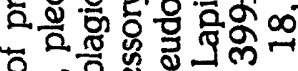

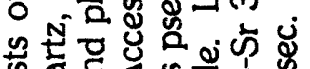

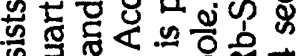

फ़े

ชั่

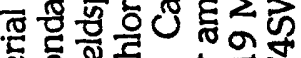

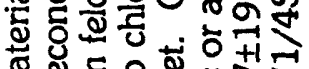

象

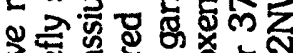

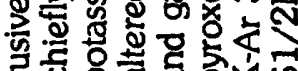

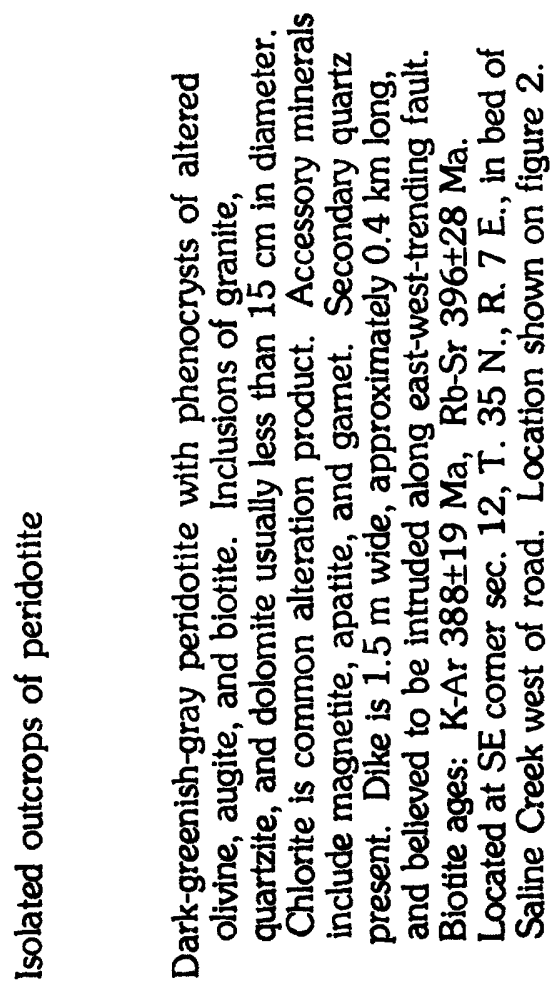

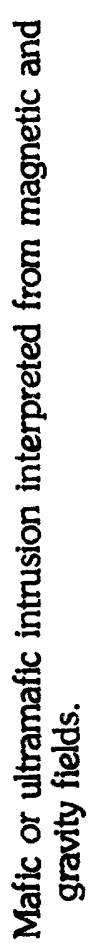

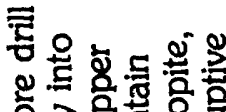

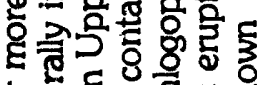

to

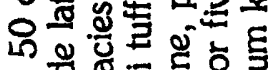

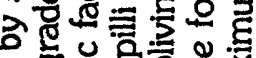

कृष

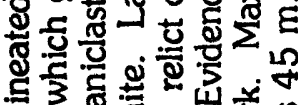

$\sum-1$

\&

象

这

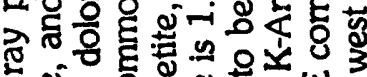

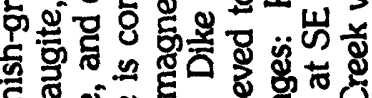

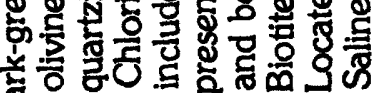

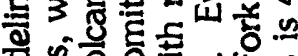

- 3 현

물웅

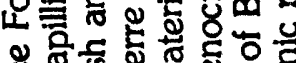

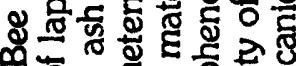

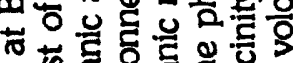

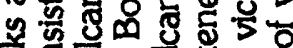

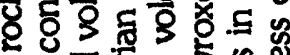

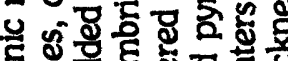

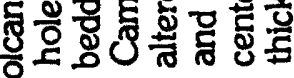

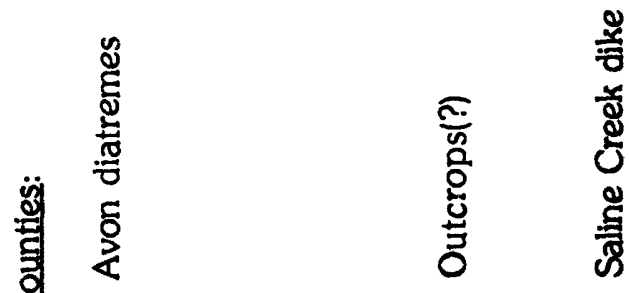
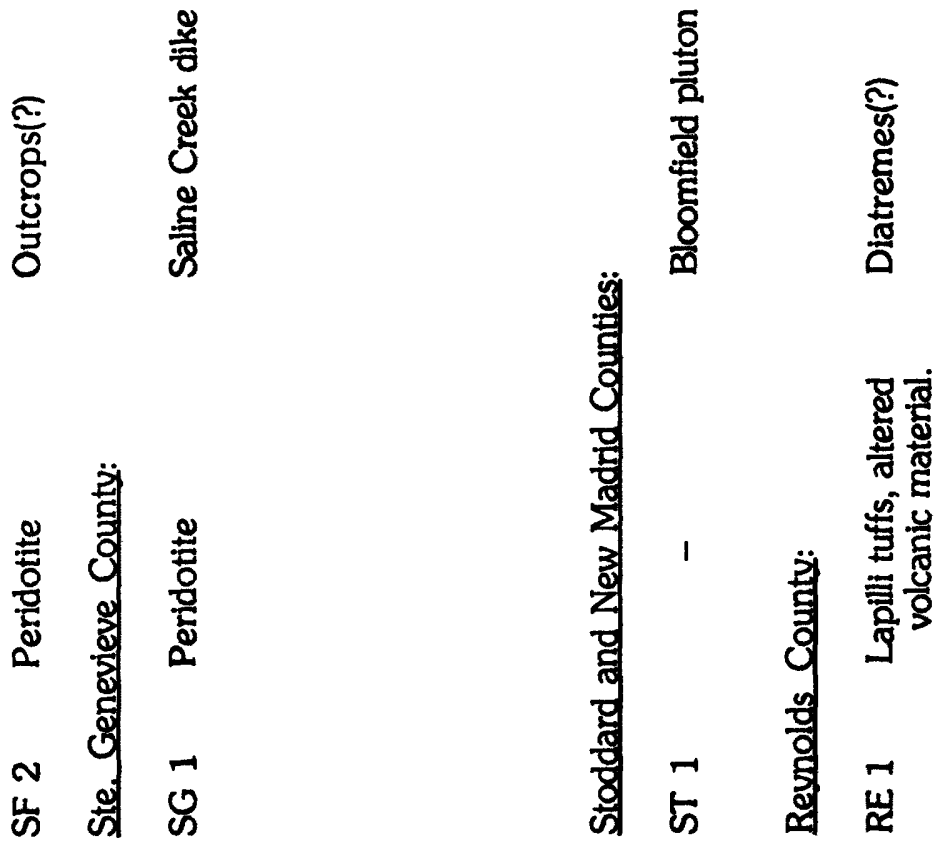


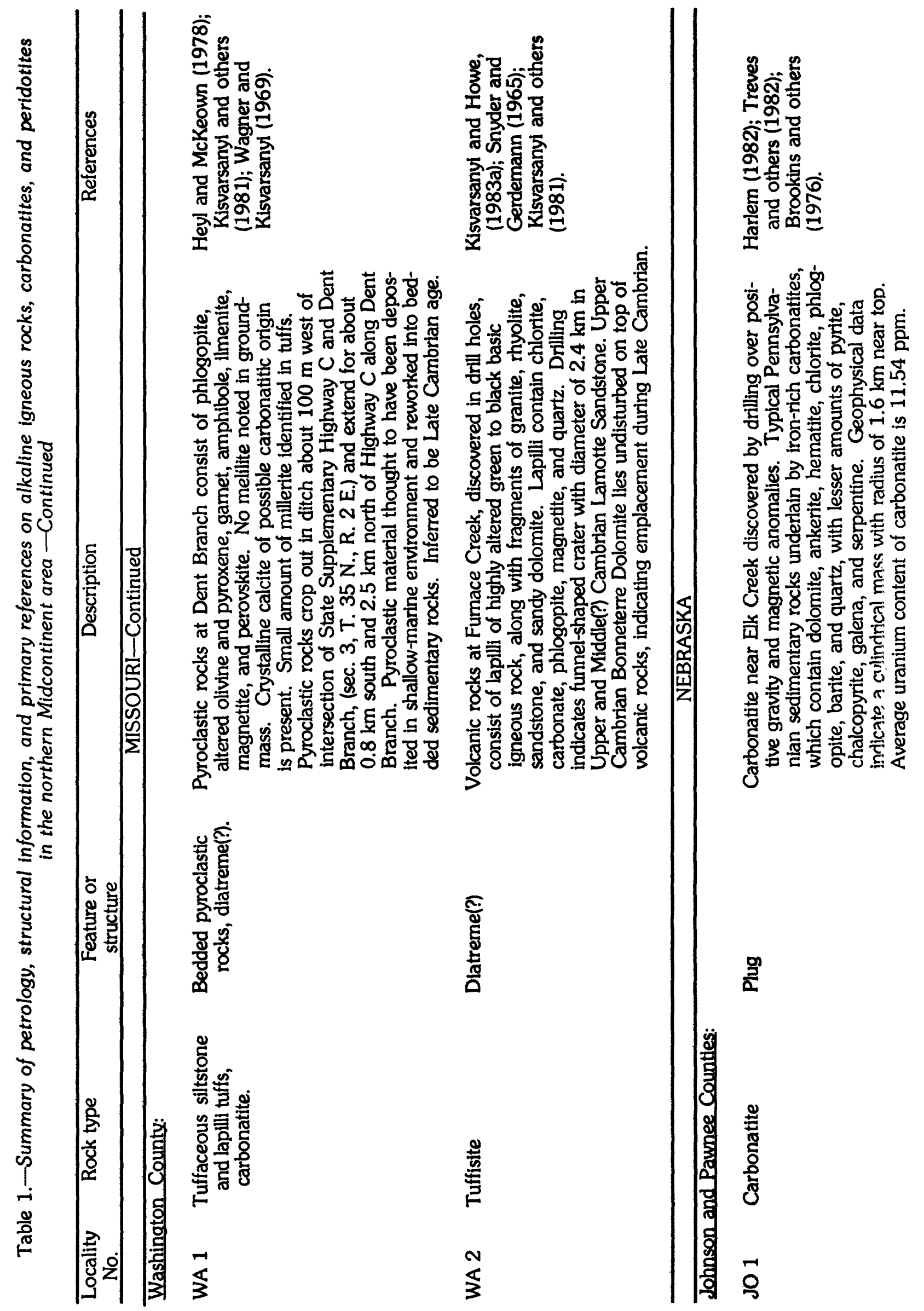




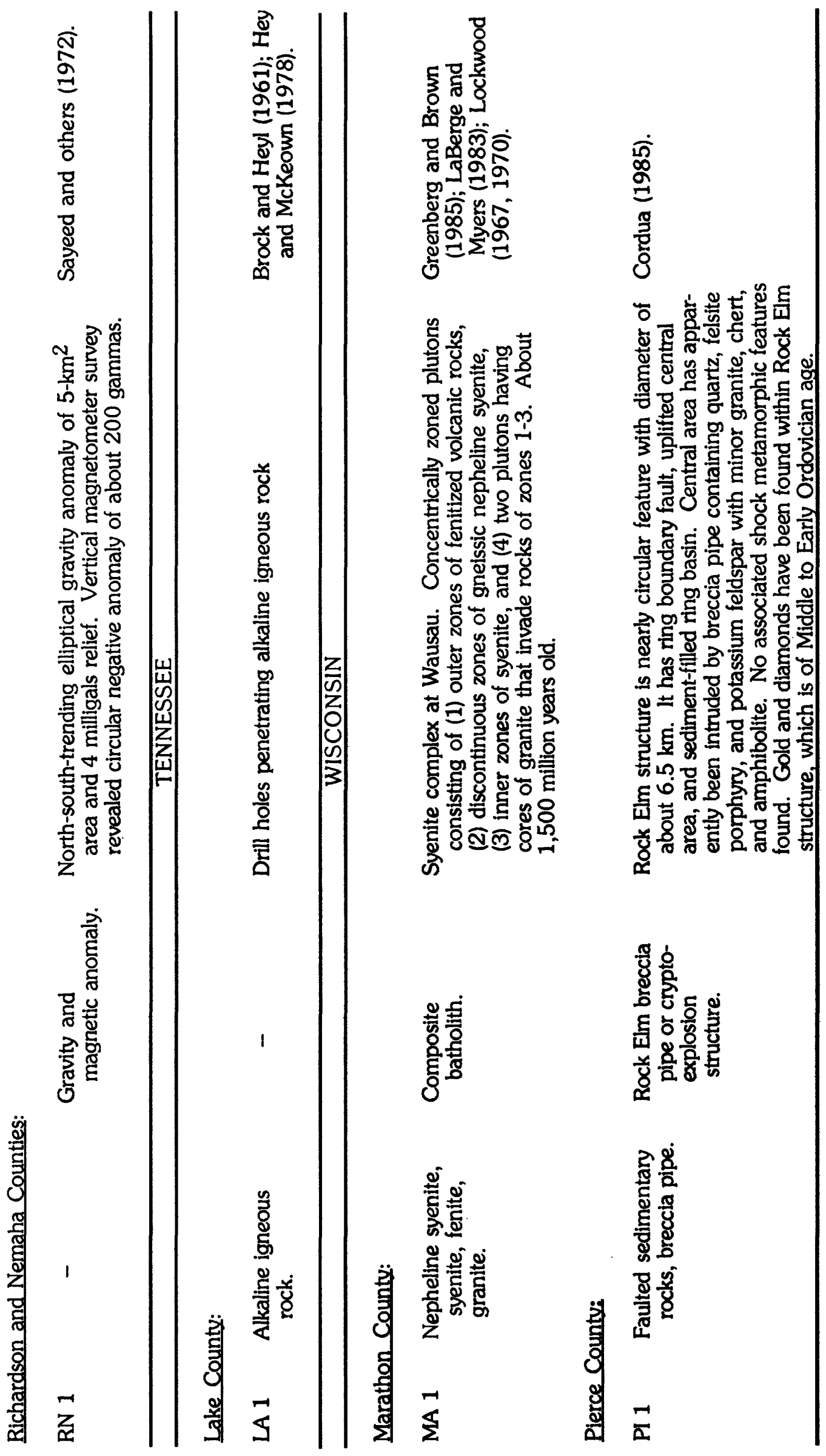


,

$+$ 